Walton in achieving close packing, but this is offered without explanation or hypothesis. Again, the permeability apparatus sketched in Fig. 5.12 is essentially similar to streaming potential cells for electrokinetic studies. The validity of using bulk fluid viscosity when the fluid is in narrow channels has been doubted in electrokinetics and could be questionable in permeametry. Packing of solid particles in liquids receives scant atten. tion; CPVC studies in paints are not mentioned. This is surprising when one might postulate that paint films approximated to two-dimensional packings and wero worthy of mention for this alone.

The gaps between theory, experiment and practice are wide and an opinion on present and future lines of investigation which might narrow these gaps would bring the book to a more definite conclusion.

Despite these minor shortcomings, W. A. Gray has produced an eminently readable book on a complex subject, and he is to be congratulated. D. P. BRYANT

\section{RADIATION BELTS}

The Radiation Belt and Magnetosphere

By Wilmot N. Hess. Pp. xii +548 . (Blaisdell, a Division of Ginn: Waltham, Mass., and London, 1968.) \$16.50.

Probably the greatest scientific achievement of space rosearch has been the discovery of the radiation belt and the advance in knowledge of the magnetosphere; incidentally this has been almost entirely American work. In the past decade the subject has advanced from very indirect observations, coupled with rather speculative theory, to an established branch of seience. This is not to say that the magnetosphere is fully understood and, of course, further advance requires further observations with satellites. The general layout of the magnetosphere is known, however, and the now numcrous workers in the field need a book of the sort reviewed here. There have been several conference reports covering the subject, but Hess has been so energetic as to cover the whole field, while his book has the advantages of a single author, particularly in the interrelating of the chapters. He also writes in a readable, informal style, and keeps theory and observations well balanced.

The short but interesting introduction includes a summary and list of problems for the future. Basic theory is given in the second chapter, including a thorough account of particle motion in a magnetic field with all three adiabatic invariants and some plasma theory. The chapter ends with a painstaking and clear doscription of the various coordinate systems used, and explanations of how particle observations are expressed and related to coordinates. The third chapter concerns the physical mechanisms which have been proposed for the sources and loss of trapped particles, though some of these mechanisms are not now believed to be important.

The fourth chapter concerns the inner zone, particularly such questions as spectrum, time decay and solar eycle changes, and includes theoretical discussion. Chapter five concerns radiation belts produced by bombs, which are scientifically useful because the source is known. The sixth chapter, on the outer belt, contains some of the most interesting physies developed in this subject, which is very close to the plasma theory developed in connexion with fusion rosearch. Hess gives extensive accounts of the theory of the "pumping" mechanism and of the interaction of the trapped particles with VLF and ELF waves. These are believed to be important, the former as an energy source and the latter in controlling the loss rate. Chapter seven on the magnotopause includes considerable theoretical discussion of instabilities and the eighth chapter on aurorae also includes recent theoretical studies. The short ninth chapter on synchrotron radiation discusses radiation from the belt produced by the large Starfish explosion and radio noise from Jupiter. Chapter ten on low energy particles discusses magnetic storms and whistlers and other VLF phenomena. Finally, there are three useful appendixes tabulating basic information.

This book is attractive particularly because of the wealth of high quality diagrams, about as many as there are pages. Hess also uses the colourful jargon of the subject, such as the leaky bucket and the windshield wiper. The very first diagram is open to criticism; it shows the 1950 s view of the geomagnetic field as a dipole in vacuum, which is unfair to theorists. This is recognizable as the influence of Brian O'Brien, which also appears at one or two other points. As a whole, however, the book is pleasing and timely and should be warmly welcomed.

J. W. Dungey

\section{Correspondence}

\section{Is Botany Dead?}

THEse correspondents refer to two articles which appeared in the November 9 issue of Nature, one on page 521 and one on page 541 .

SIR,-You ask if botany is dead. You may be interested to hear, therefore, that the British Association has recently set up a committee, of which I am chairman, to consider the "Future of Botany".

Yours faithfully, P. W. BRIAN

Botany School,

Downing Street,

Cambridge, CB2 3EA.

SIR,- - Your editorial in Nature referring to the article by Sir Frank Engledow on botanical studies in this country explains the situation as it exists, but hardly suggests how it might be improved.

Unfortunately, the popular derisive image of botany originates at VI Form level, but we feel that this image would quickly change if the whole scope of botany could be presented to the potential university student. Too much emphasis is placed on systematics, especially by concentrating study on the detailed life histories of selected representative plants at A-level. Are all fern prothalli heart shaped?

If teachers would digress from these A-level species and inject some enthusiasm into the lessons of their chosen subject, the situation might change. The Nuffield scheme, through its scientific approach by investigating problems experimentally, should help to introduce some vitality into the subject. Botany could also be brought into perspective by emphasizing the ecological, physiological and economic aspects and in particular the importance of these subjects to man.

If this fails, then we think that the pundits will have a dubious pleasure in being correct.

$$
\begin{aligned}
& \text { Yours faithfully, } \\
& \text { A. MACKIE } \\
& \text { C. SCARD } \\
& \text { P. J. WINFIELD }
\end{aligned}
$$

Botany Department,

University of Southampton.

Sir,--As long as there are people on Earth to feed and an environment fit for plants and humans to grow in, the service of botanists will continue to be needed. Curiosity and love of nature will ensure that many young men and women are attracted into this field. But the teaching they 
receive and their prospects for the future leave much to be desired.

There are far too many departments with only a handful of staff teaching small classes of students. The teaching staff will certainly give of their best, but the spectrum of botany that they are able to cover is bound to be severely limited. Moreover, where staff are few there is little or no flexibility for students to choose botanical courses according to their interest. Unlike physical sciences, many botanical disciplines do not have to follow a rigorous step by step progression. Coupled with the absence of any movement of undergraduate students between universities, it is little wonder that many are dissatisfied. It can be very disheartening for a young man or woman interested in plant diseases, for example, to find that in three years they are scarcely mentioned.

Out of botany have developed the applied departments of agriculture, forestry and horticulture. Yet the modern "pure" botany department is completely divorced from these "applied" branches. Surely this is the greatest mistake of all. Apart from the very real disadvantages to botanical education, it has meant that too much of botanical research is now in areas for which the training of a biochemist is more appropriate. Whereas the wholeplant botanist finds the lack of ground space available, the lack of good glasshouses and of sites to place them, and of trained gardeners to tend them, extremely frustrating, it is a regrettable truth that many botanists are simply not interested in plants except as homogenates.

Biologists have often to handle a multiplicity of variables as complicated to analyse as any facing an engineer, yet there is a common reluctance to include in their teaching programmes even the simplest statistical methods of analysis, and the planning of experiments goes unheeded. On the other hand, we find departments priding themselves on the fact that over the last decade they have successfully displaced the monotony of the detailed learning of the principal characteristies of the families and genera of flowering plants; instead the modern student learns the intricate details of metabolic pathways. Thus one kind of descriptive botany is replaced by another, and the overall approach to training botanists is no more scientific than before.

If today the function of botanists in society is in question, then university departments must carry some of the blame, for without doubt many potential and existing botanists, not to mention the general public, are struggling through the trees looking for the wood.

\section{Yours faithfully,}

R. A. E. Truney-Bassett

University College of Swansea,

Department of Genetics,

Singleton Park,

Swansea, Wales.

\section{New Materials Make their Mark}

Sir,--Our attention has been drawn to a letter by A. E. Standage in the October 26 issue of Nature $(220,412$; 1968). While Standage is correct in saying that the first worker to make carbon fibres from polyacrylonitrile was A. Shindo ${ }^{1}$, it must be pointed out that the highest Young's modulus he obtained was $24 \times 10^{6}$ pounds inch-2 and the highest fibre strength was $141 \times 10^{3}$ pounds inch ${ }^{-2}$. It was only when we used tension applied to the fibres at an early stage of the preparation, which Shindo did not do, that we obtained carbon fibres of moduli in the range 60 to $70 \times 10^{6}$ pounds inch-2 and of strengths about $300 \times 10^{3}$ pounds inch-2. These values are more than twice those obtained by Shindo. Our initial publication ${ }^{2}$ announcing the properties and applications of highmodulus high-strength carbon fibres was postponed for several months and Dr Standage was made aware of our preparative methods and results well in advance of the publication by Prescott and Standage ${ }^{3}$. We compared the results obtained by Shindo with our own results in a letter to Nature ${ }^{4}$ and recently presented a paper at an American Chemical Society symposium on carbon and graphite fibres (September 10, 1968) in which we gave the results of laboratory experiments showing the effect of tension applied to the fibres at the first stage of preparation. The work of Shindo was fully acknowledged and contrasted with our own. The fact that patents for our method of making carbon fibres from PAN fibres have been granted in the UK' ${ }^{5}$ and the $U^{6}$ shows that we do have a new technology of making high-modulus highstrength carbon fibres from PAN fibres.

\section{Yours faithfully, WIILIAM WaTT WILLIAM JOHNSON}

Ministry of Technology,

Royal Aircraft Establishment,

Materials Department,

R.49 Building,

Farnborough, Hants.

${ }^{2}$ Shindo, A., Rep. No. 317, Gov. Ind. Res. Inst. (Osaka, Dec., 1961).

2 Watt, W., Phillips, L. N., and Johnson, W., The Engineer, 221 (1966).

${ }^{3}$ Prescott, R., and Standage, A. E., Nature, 211, 169 (1966).

"Moreton, R., Watt, W., and Johnson, W., Nature, 213, 690 (1967).

${ }^{5}$ British Patent No. 1,110,791.

- United States Patent No. 3,412,062.

\section{Parapsychology}

SiR,--I was interested to see "parapsychology" as a subject heading in the contents list for Nature $(220, \mathrm{xv}$; 1968). I find the word parapsychology odd: almost as odd as "extrasensory" when used in conjunction with perception. At the least it indicates muddled thinking, and at the worst an untenable attitude to research. If one allows that any or all of the range of phenomena endearingly called parapsychology exist, one must also allow that an objective experiment is impossible. An amusing example of what I mean can be found in the tortuous attempts to separate telepathic from precognitive, or, worse, psychokinetic effects on the part of the parapsychologists themselves.

Let us consider a parable, which I believe is relevant. A poor man had only one hundred pence, but a certain statistical insight. Wishing to enrich himself, he approached a wealthy and still optimistic gambler, telling him that he had an infallible method for selecting lucky coins which had the apparently marvellous property of consistently coming up heads (or tails, if the gentleman preferred) more often than not. His potential client was somewhat sceptical, but his optimism made him realize that he at least could not lose by watching the demonstration. The poor man tossed all one hundred coins ten times; twenty-two of them came up heads seven times or more. These twenty-two seeming relatively talented, he tossed them again, ten times each. This time selective pressure was more intense and only five coins survived with seven or more heads (although one had ten). The gambler was by now fascinated and could scarcely wait for the climax. It came; on the third series of trials only one coin came up heads even as much as seven times. However, it had already come up heads more than seven times in both the previous trials and the cumulative odds against its particular performance were apparently at least $10^{7.6}$ to 1 , quite enough to impress any gambling man.

The parable unfortunately ends here, the scroll on which it is written having been torn asunder, possibly by someone in a considerable fury.

\section{Yours faithfully,}

ANTHONy RoBertson

The University of Chicago,

Chicago, Illinois 60637. 